\title{
FOOD ADDITIVES AND PRESERVATIVES AS SLOW POISONS
}

\author{
Dr. Ali Abusaloua ${ }^{*}$, Dr. Guma Mohamed ${ }^{2}$, Eng. Abdulbassit Ali ${ }^{3}$, Eng. Waleed \\ Zahmol $^{4}$ \\ ${ }^{1}$ Chemical Engineering Department, Sabratha Faculty of Engineering, Sabratha Universiity \\ ${ }^{2,3,4}$ Environmental Engineering and Naeutral Resources Department, Sabratha Faculty of \\ Engineering, Sabratha Universiity \\ *Corresponding author email: drabusaloua@gmail.com
}

\begin{abstract}
Food additives are natural or synthetic substances that can be added to foodstuff in small amounts to perform technological functions, namely color, sweetness, nutrients, or to extend shelf life. Due to Food processing technology revolution for all kinds of foods, additives and preservatives that are being added in food processing are increased.

Food additives toxicology appear in a long term combined effect, where a cumulative effect of their hazards as "Slow Poisons" will increase the risk possibility of disease or premature of death. These slow poisons have been accumulated in our body since birth and are embedded in every cell structure and organ and disrupt the natural chemistry of your body. This paper has been reported that chemicals which are used as preservatives or additives have many side effects. The reaction of preservatives and additives can be very danger over time as slow poisons, to mild effect life threatening. It is best to eat a preservative-free diet if at all possible.
\end{abstract}

\section{Introduction}

Natural foods are foods that unprocessed and don't contain any artificial preservatives or additives. Natural foods are the best source of nutrition and health.

Natural methods of preservation usually aim to exclude air, moisture, and microorganisms, or to provide environments in which organisms that might cause spoilage can't survive. Natural way of food preservation can be done by boiling, freezing, pasteurizing, dehydrating, smoking, and pickling.

Natural foods have a limited shelf life, in order to increase the shelf life and maintain the quality, certain preservatives are used, these preservatives may have some harmful effects on human health. Substances that added to natural foods to preserve flavor and increase their life are named as additives. The additives and preservatives prevent bacterial and fungal growth due to excess water to the food. Food chemistry is the study of chemical processes and interaction of all biological and non-biological components that contained in the natural or artificial foods [1]. 
Additives and preservative are named by the United States food and drug administrations (FDA) as " any substance the intended use of which results or may reasonably be expected to result, directly or indirectly; in it's becoming a component or otherwise, affecting the characteristic of any food. Besides, in the EU every food additives has a code that include the letter E ( for Europe) followed by three or four digits. The numbering scheme follows that of the International Numbering System (INS) as determined by the codex Aliment Arius committee [2]. Additives also control the acid-base balance of foods while preservatives slow the process of product spoilage caused by mould, air, bacteria, fungi, or yeast [3].

Food additives can be classified to natural or artificial, direct or indirect additives. The effects of food additives may be immediate or may be harmful in the long run as a slow poisons in case of constant exposure.

During the past few decades the use of artificial additives has increased tremendously. Increased consumptions has been facilitated by rising income, urbanization, food industry, media advertisement, and trade liberalization, mainly in developed countries [4]. Influenced by this reality, populations of the developed countries are undergoing a rapid change towards " transition nutrition". Thus, the traditional dietary pattern is gradually being replaced by the fast foods [5].

This paper aims to review the available literature on the various effects of food additives and preservatives in human.

\section{Types of Food Additives}

\section{Natural preservatives}

Natural food preservatives come in the form of salt, alcohol, vinegar, etc. traditional preservatives in food that also used at home while making pickles, jams, juices. Sometimes sugar combined alcohol for preservation of luxury products such as fruit in brandy and other asperities.

\section{Chemical Preservatives and Additives}

Artificial preservatives are the chemical substance that stop or delay the growth the bacteria thereby preventing spoilage and it's discoloration [2-8]. Examples of chemical food preservatives are shown in Table 1.

Table (1): Chemical Peservative.

\begin{tabular}{|c|c|c|c|c|c|c|}
\hline DESIGNATION & $\begin{array}{c}\text { acid } \\
\text { acetic }\end{array}$ & $\begin{array}{c}\text { benzoic } \\
\text { acid }\end{array}$ & $\begin{array}{c}\text { Propionic } \\
\text { acid }\end{array}$ & $\begin{array}{c}\text { Sorbic } \\
\text { acid }\end{array}$ & $\begin{array}{c}\text { Sulphur } \\
\text { dioxide }\end{array}$ & $\begin{array}{c}\text { citric } \\
\text { acid }\end{array}$ \\
\hline $\begin{array}{c}\text { ADDITIVE } \\
\text { CODE }\end{array}$ & E260 & E210 & E280 & E200 & E220 & E330 \\
\hline
\end{tabular}




\section{Antioxidants}

Antioxidants prevent foods from oxidizing or going rancid. Oxidation is a real problem for food products which causes raw apples and potatoes to go brown. Antioxidants are used as food additives to preserve food for a longer period of time. They act as oxygen scavengers, as the presence of oxygen in the food helps the bacteria to grow that can ultimately harm the food, Ascorbic acid (vitamin C) used in beers, cut fruits, dried potatoes and jams helps in preventing the discoloration of food by preventing the oxidation and also act as a substitute of vitamin $\mathrm{C}$ in potatoes that is lost during processing. Some commonly used antioxidants are shown in Table 2.

Table (2): Antioxidants.

\begin{tabular}{|c|c|c|c|c|c|c|}
\hline $\begin{array}{c}\text { DESIGNATIO } \\
\mathbf{N}\end{array}$ & $\begin{array}{c}\text { Butylated } \\
\text { hydroxyanisol } \\
\mathbf{e}\end{array}$ & $\begin{array}{c}\text { Ascorbyl } \\
\text { palmitat } \\
\mathbf{e}\end{array}$ & $\begin{array}{c}\text { Calcium } \\
\text { ascorbat } \\
\mathbf{e}\end{array}$ & $\begin{array}{c}\text { Ascorbi } \\
\mathbf{c} \text { acid }(\end{array}$ & $\begin{array}{c}\text { hydroge } \\
\mathbf{n} \\
\text { peroxide }\end{array}$ & $\begin{array}{c}\text { Hypochlorou } \\
\text { s acid }\end{array}$ \\
\hline $\begin{array}{c}\text { ADDITIVE } \\
\text { CODE }\end{array}$ & $\mathrm{E} 320$ & $\mathrm{E}(304)$ & $\mathrm{E} 302$ & $\begin{array}{c}\text { vitamin } \\
\mathrm{C}\end{array}$ & $\mathrm{H} 2 \mathrm{O} 2$ & $\mathrm{HClO}$ \\
\hline
\end{tabular}

\section{Sweeteners}

Sweeteners provide sweet taste similar to that of sugar with and without any extra calories. Caloric sweeteners, artificial sweeteners are synthetic sugar substitutes, but may be derived from naturally occurring substances, including herbs and sugar itself. Artificial sweeteners are also known as intense sweeteners because they are many times sweeter than sugar but contribute only few calories when added to food and they don't raise blood sugar levels, Examples of sweeteners are shown in Table 3.

Table (3): sweeteners.

\begin{tabular}{|c|c|c|c|c|}
\hline DESIGNATION & Sucralose & Alitame & Aspartame & Sacharin \\
\hline ADDITIVE CODE & E420 & E956 & E951 & E954 \\
\hline
\end{tabular}

\section{Color Additives}

A color additives is any dye, pigment or substance that can impact color alone or through reaction with other substances, when added to food, drug or cosmetic applied to the human body. Any substance not normally consumed as a food in itself and not normally used as a characteristic ingredient of food, whether or not it has nutritive value. Food colors are present in many foods including snack foods, margarine, cheese, jams and jellies, desserts, drinks, etc. Examples of color additives are shown in Table 4. 
Table (4): color additives.

\begin{tabular}{|c|c|c|c|c|c|}
\hline DESIGNATION & Curcumin & $\begin{array}{c}\text { Brilliant } \\
\text { blue FCF }\end{array}$ & Tartrazine & $\begin{array}{c}\text { Sunset } \\
\text { Yellow }\end{array}$ & $\begin{array}{c}\text { Orange } \\
\text { Yellow }\end{array}$ \\
\hline ADDITIVE CODE & E110 & E133 & E102 & FCF & S \\
\hline
\end{tabular}

\section{Flavor Enhancer}

Flavor enhancer is used in savory foods to enhance the existing flavor in the food. They themselves don't have any flavor but enhance the flavor of food products. Natural flavor enhancers increase the stability of food, as salt is commonly used as a natural flavor enhancer for food products. Salt is commonly used as a natural flavour enhancer for food products. Inosinic acid is most commonly used flavour enhancers. Flavour enhancers are also used in a wide range of foods including savoury snacks, prepared meals and condiments. Examples of flavor enhancer is shown in Table 5.

Table (5): flavor Enhancer.

\begin{tabular}{|c|c|c|c|c|c|c|c|c|}
\hline $\begin{array}{c}\text { DESIGNA } \\
\text { TION }\end{array}$ & $\begin{array}{c}\text { Disodium } \\
\mathbf{5}^{\prime} \text { - } \\
\text { ribonucle } \\
\text { otides }\end{array}$ & $\begin{array}{c}\text { Monoso } \\
\text { dium } \\
\text { Glutama } \\
\text { te }\end{array}$ & $\begin{array}{c}\text { Monopota } \\
\text { ssium } \\
\text { Glutamate }\end{array}$ & $\begin{array}{c}\text { Calciu } \\
\mathbf{m} \\
\text { Digluta } \\
\text { mate }\end{array}$ & $\begin{array}{c}\text { Guan } \\
\text { ylic } \\
\text { acid }\end{array}$ & $\begin{array}{c}\text { Sodiu } \\
\text { m } \\
\text { Guan } \\
\text { ylat }\end{array}$ & $\begin{array}{c}\text { Eth } \\
\text { yl } \\
\text { Mal } \\
\text { tol } \\
(),\end{array}$ & $\begin{array}{c}\text { Calciu } \\
\mathbf{m} \\
\text { Gluta } \\
\text { mate } \\
(),\end{array}$ \\
\hline $\begin{array}{c}\text { ADDITIVE } \\
\text { CODE }\end{array}$ & E635 & E621 & E623 & E626) & E627, & E630 & $\begin{array}{c}\text { E63 } \\
7\end{array}$ & 623 \\
\hline
\end{tabular}

\section{Anti-Caking Agents}

Anti-caking agent is a type of food additive that are added to keep ingredients from clumping together after being packaged. Anti-caking agent act either to absorb moisture or act as a sealant and repel water and oil. Sodium ferrocyanide, Decahydrate, Propylene glycol, Magnesium silicate are the most commonly used anti-caking agents. Examples of Anti-caking agents are shown in Table .6.

Table (6): Anti-caking Agents.

\begin{tabular}{|c|c|c|c|}
\hline DESIGNATION & Bentonit & Calcium aluminum silicate & Calcium silicate \\
\hline ADDITIVE CODE & E558 & E556 & E552 \\
\hline
\end{tabular}

\section{Emulsifiers}

When water and oil are mixed together and vigorously shaken, oil droplets disperse in water and upon stopping of shaking, the phase start to separate. However, when emulsifier 
is added to the system, the droplet remain dispersed, and a stable emulsions is obtained. The emulsifier may be an aerating agent, starch complex agent and / or crystallization inhibitor. Nature is good at making emulsions, and the classic example is milk, where a complex mixture of fat droplet is suspended in an aqueous solution. are mixtures of phospholipids such as phosphatidy 1 choline and phosphatidy 1 ethanolamine, and are usually extracted from sources such as egg yolk and soybeans. The precise composition of the phospholipids depends on the source. They are used for salad dressings, baked goods and in chocolates, Ammonium salt of PolyGlycerol Ester (PGE), CSL Calcium stearoyl diLaciate are used extensively as emulsifiers in various food items. Examples of Emulsifiers are shown in Table .7.

Table (7): Emulsifiers.

\begin{tabular}{|c|c|c|c|c|c|}
\hline DESIGNATION & PG Ester & $\begin{array}{c}\text { Sorbitan } \\
\text { Ester }\end{array}$ & $\begin{array}{c}\text { Phosphatidic } \\
\text { acids }\end{array}$ & $\begin{array}{c}\text { Sorbitan } \\
\text { Monostearate }\end{array}$ & Lecithins \\
\hline ADDITIVE CODE & PGME & SOE & E442 & E491 & E322 \\
\hline
\end{tabular}

\section{pH Controlling Agents}

The $\mathrm{pH}$ is the negative logarithm of the hydrogen-ion concentration in aqueous solution. The $\mathrm{pH}$ of the food is the measure of that product's acidity or alkalinity which maintains flavor of food. The acid ingredients maintain a constant acid level by lowering the $\mathrm{pH}$ and thus preserve foods by inhibiting microbial growth. Natural acids include acetic acid or vinegar and citric acid from citrus, malic acid and tartaric acid (a weak acid). Commonly used acidulants are, Alkaline compounds such as Potassium citrate, Calcium carbonate, Calcium acetate, Sodium bicarbonate and Sodium lactates are also used to neutralize excess acids that otherwise produce unwelcome Examples of $\mathrm{pH}$ controlling agents are shown in Table 8.

Table (8): pH Controlling Agents.

\begin{tabular}{|c|c|c|c|c|c|}
\hline DESIGNATION & Acetic acid & $\begin{array}{c}\text { Fumaric } \\
\text { acid }\end{array}$ & Phosphoric acid & Malic acid & Lactic acid \\
\hline ADDITIVE CODE & E260 & $2977^{\circ}$ & E338 & E296 & E270 \\
\hline
\end{tabular}

\section{Harmful Effect of Preservatives}

People consume variety of foods with several preservatives, so it is difficult to find out the exact substance which causes the allergy or disease. Side reactions of these preservatives can be immediate or build up as a slow poison in the body over time. There are certain harmful effects of using chemicals as preservatives or additives such as $[6,7,8,9]$; Sulphites are common preservatives used in various fruits, may have side effects in form of headaches, palpitations, allergies, and even cancer. Nitrates or nitrites: these additives are used as curing agents in meat products. It gets converted into nitrous acid when consumed 
and is suspected of causing stomach cancer, Bensoates are used in foods as antimicrobial preservatives, and have suspected to cause allergies, asthma and skin rashes. Sorbate/ or sorbic acid are added to foods as antimicrobial preservatives. Reactions to sorbate are rare, but have included reports of utricaria and contact dermatitis. Also, a nuclear radiation when used for preservation doesn't make foods radioactive, but may cause changes in food colour or texture.

\section{Conclusions}

Preservative are used to increase the shelf life of food and maintain the quality for longer time. It has been reported that chemicals which are used as preservatives or additives have many side effects. The reaction of preservatives and additives can be very mild to life threatening. It is best to eat a preservative-free diet if at all possible.

There are a significant number of food preservatives (antimicrobial agents) that protect foodstuff against the action of microorganisms (fungi and/or bacteria) and thereby extend the shelf life. Jointly to other techniques, such as hermetically sealed packaging and cooling, food preservatives have an incontestable importance in food technology. The agro food companies use preservatives in pre-cooked food, meat products, sauces, cheese, canned fish, meat, vegetables and fruits, packaged bread, confectionery, cooked and frozen crustaceans, and many other food products in which case all additives and all uses are regulated by the EU. However, the use of some of these food additives is not absent side effects to health. Food preservatives, such as nitrites and sodium and potassium nitrates, the various benzoates, sulphites, diphenyl, orthophenylphenol and hexamethylenetetramine present meaningful side effects, and should be used in the smallest possible amount, maintaining the necessary technological features. Moreover, other food preservatives, such as sorbic acid and sorbates, acetic acid and acetates, propionic acid and propionates, when applied to foodstuffs do not appear to have side effects in the amounts indicated by the EU regulation.

\section{References}

- [1] Alshamari. E, Bano. S, Shankity. I, The effect of Preservatives and Flavour additives on the Production of Oxygen- Free radical by isolated human Neutrophils, Int. Journal of Nutrition and Food Sci. 3 (3), 2014, 210-215.

- [2] Inetianbor. J, Yakubu. M, Ezeonu. C, Effects of Food additives and Preservatives on Man, Asian J. of Sci. and Tech., vol. 6, Issue. 02, Feb. 2015, pp.11118-1135.

- [3] Sharma. S, food Preservative and their Harmful effects, Int. J of Sci. and Res. Publications, Vol. 5, Issue. 4, April 2014.

- [4] Silva. M, Lidon. F, Food Preservatives- overview on applications and side effects, Emirates Journal of food and Agriculture 28 (6), 2016, P. 366-377.

- [5] Dar. H etal, Immunomodulatory Effects of Food Additives, International Journal of Immunotherapy and cancer research, 3 (2), 2017, p. 019-031. 
- [6] Arrora. A, Mahjan. S, Gupta. P, Kapoor. S, Is chemical Safety of Food Hazardous? Dangers of Food Preservatives, J. Indian Acad Forensic Med, 31 (4), 2010.

- [7] International Food Information Council Foundation \& US Food and Drug Administration, Food ingredients and colors, US Food and Drug Administration 1-8. 2010, Link: https://goo.gl/KvObgl.

- [8] Belly Bytes-Types of Food additives; Link: https://goo.gl/5mguW5.

- [9] efsa European Food Safety authority, 2016, Link: https://goo.gl/FNbOjZ.

- [10] Henry. G, Heinke. G, Environmental Science and Engineering, prentice-Hall, /Inc., Englewood-cliffs, $1^{\text {st }}$ edition, 1989, USA.

- [11] Masters. G, Introduction to Environmental Science and Engineering, prentice-Hall, Inc., Englewood-cliffs, $1^{\text {st }}$ edition, 1991, USA.

- [12] Dr. Debs. Academia dictionary for Scientific and Technical Terms, Academia international for publishing and printing, $1^{\text {st }}$ edition, 1988, Beirut, Lebanon. 